\title{
Growth and Yield of Rice Planted in a Tidal Soil Under NPK in situ and Cow Manure Application
}

\author{
Dedik Budianta $^{1,3 *}$, Jerry Alfredo Lee Panggar Bessy ${ }^{2}$ and Agus Hermawan ${ }^{1}$ \\ ${ }^{1}$ Department of Soil Science, Faculty of Agriculture, University of Sriwijaya, and ${ }^{2}$ Department of \\ Agroecotechnology, Faculty of Agriculture, University of Sriwijaya \\ Jl. Raya Palembang-Prabumulih KM 32 Indralaya, Ogan Ilir, South Sumatera, 30662 Indonesia \\ *e-mail:dedik_budianto@yahoo.com
}

Received February 23, 2021; Revised March 12, 2021; Accepted 22 April 2021

\begin{abstract}
The specific location fertilization or in situ fertilization rate is a dynamic application and management method dynamically adapted to the plant's need according to location and season related to soil chemical properties and aims to increase farmer profit. This greenhouse experiment aimed to evaluate the NPK fertilizer dose based on in situ soil chemistry of tidal swamp compared to NPK recommendation combined with cow manure from the local farm. These pot experiments were conducted from June to October 2019 in a Greenhouse of Soil Science Department, Faculty of Agriculture, Sriwijaya University, Indralaya, Ogan Ilir of South Sumatra. This experiment used a factorial completely randomized design with two factors and three replications. The first factor was NPK fertilizer rate consisting of two levels $\left(200 \mathrm{~kg} \mathrm{ha}^{-1} \mathrm{Urea}, 100 \mathrm{~kg} \mathrm{ha}^{-1} \mathrm{SP}-36\right.$, and $\left.100 \mathrm{~kg} \mathrm{ha}^{-1} \mathrm{KCl}\right)$ from recommended fertilizer, and $\left(102 \mathrm{~kg} \mathrm{ha}^{-1}\right.$ Urea, $0 \mathrm{~kg} \mathrm{ha}^{-1} \mathrm{SP}-36$, and $\left.66 \mathrm{~kg} \mathrm{ha}^{-1} \mathrm{KCl}\right)$ from the in situ soil analysis. The second factor was cow manure with four levels $\left(2,6,8\right.$ and $\left.10 \mathrm{Mg} \mathrm{ha}^{-1}\right)$ The result showed that recommended NPK combined with $10 \mathrm{Mg}$ $\mathrm{ha}^{-1}$ cow manure was the best for rice production in tidal lowland and produced $2.5 \mathrm{Mg} \mathrm{ha}^{-1}$. However, this result was not significant compared to NPK specific locations combined with the same rate of cow manure.
\end{abstract}

Keywords: Cow manure, NPK, rice, site-specific fertilization, tidal swampland

\section{INTRODUCTION}

Rice production in a tidal swamp of Indonesia is relatively low (less than $2.5 \mathrm{Mg} \mathrm{ha}^{-1}$ ) (Mawardi et al. 2020); it is lower than in irrigated paddy fields (Senewe and Alfons 2011). Low productivity is probably due to low soil fertility and high acidity of the soil combined with a high level of Exchangeable$\mathrm{Al}$ (Imanudin and Armanto 2012), and the tidal soil contained sulfidic material called pyrite (Prasetyo et al. 2001).

The total tidal swamp area in Indonesia is quite large, amounting to 20.1 million hectares, and the potential area for extension agriculture is about 9.53 million hectares; while only 2.27 million hectares have been reclaimed (BBPPSLP 2016), and total reclaimed tidal flat in South Sumatra is about 329.897 ha (Prasetyo et al. 2001). Recently, rice varieties used for specific tidal swamp locations can increase

J Trop Soils, Vol. 26, No. 2, 2021: 51-62

ISSN 0852-257X; E-ISSN 2086-6682 rice yields (Hairmansis et al. 2010). Tidal swamp in South Sumatra has been reclaimed since 1961 (Imanudin and Armanto 2012). Prasetyo et al. (2001) reported that tidal soils found in Musi Banyuasin, South Sumatra, are classified as Sulfic Endoaquept, Histic Sulfaquent, Typic Sulfaquept, Fluvaquentic Endoaquept, and Sulfic Hydraquent. Soils of the tidal flat areas in Musi Banyuasin of South Sumatra are developed from marine sediment. This type of soil is characterized by the presence of sulfidic materials, which, upon oxidation after exposure to air by land reclamation, and if conditions are suitable, may result in highly acidic soil ( $\mathrm{pH}$ less than 3.5). Since the acidity comes from sulphuric acid production, the highly acidic soils are called acid sulfate soils. It causes high soil acidity and poor fertility (Prasetyo et al. 2001).

Optimizing and utilizing tidal land for agriculture is faced many problems and obstacles, including the soil biophysical and socio-economic aspects. The biophysical constraint of the tidal land includes soil acidity originating from the pyrite oxidation, organic 
acids releasing from organic material of peat, and low macro and micro essential nutrient availability. The soil acidity of tidal land is high or $\mathrm{pH}$ less than 4.0 combined with high $\mathrm{Fe}^{2+}$ and the shallow pyrite layer (Saragih 2013; Mawardi et al. 2020). Acidity is the main challenge in tidal swampland management because of low soil $\mathrm{pH}$, which is generally $3.5-4.5$, while cultivated crops generally grow well at a $\mathrm{pH}$ of 5.5-7.0 or in a neutral condition. Soil with low $\mathrm{pH}(\mathrm{pH}$ less than 4.0) or high acidity can increase the solubility of $\mathrm{Al}, \mathrm{Fe}$, and $\mathrm{Mn}$ in soil. Iron and $\mathrm{Mn}$ generally poison food crops in $\mathrm{Fe}^{2+}$ and $\mathrm{Mn}^{2+}$ under anaerobic conditions (Mulyani and Las 2008).

One effort to manage the tidal swampland fertility is by applying balanced inorganic fertilizer and improving the soil $\mathrm{pH}$. Fertilizer as a source of nutrients has played a vital role in increasing rice productivity. According to Rochmat and Sugiyanta (2010), applying the NPK combination of recommended fertilizer dose $\left(200 \mathrm{~kg}\right.$ Urea ha ${ }^{-1}+$ $100 \mathrm{~kg} \mathrm{SP}-36 \mathrm{ha}^{-1}+100 \mathrm{~kg} \mathrm{KCl} \mathrm{ha}{ }^{-1}$ ) and cow manure dose $\left(10 \mathrm{Mg} \mathrm{ha}^{-1}\right)$ on rice fields can increase agronomic effectiveness. To increase rice yield in tidal soil, this research was conducted to study the use of NPK and cow manure fertilizer dose on a swampland area; thus, using the correct dose of cow manure could be expected to increase growth and rice yields, and the in situ dose of NPK fertilization was also examined.

\section{MATERIALS AND METHODS}

\section{Study Site}

A greenhouse experiment was conducted from June to October 2019 in the Laboratory of Soil Science Department. Soil analysis was carried out at the Laboratory of Chemistry, Biology, and Soil Fertility, Department of Soil Science, Faculty of Agriculture, Sriwijaya University, Indralaya, South Sumatra.

\section{Research Design}

A pot experiment was designed using a randomized factorial design. The first factor was the dose of inorganic fertilizers, which were a recommended NPK fertilizer dose ( $200 \mathrm{~kg} \mathrm{ha}^{-1}$ Urea, $100 \mathrm{~kg} \mathrm{ha}^{-1} \mathrm{SP}-36,100 \mathrm{~kg} \mathrm{ha}^{-1} \mathrm{KCl}$ ), and a specific location NPK fertilizer dose (102 kg ha-1 Urea, $0 \mathrm{~kg}$ $\mathrm{ha}^{-1} \mathrm{SP}-36$ and $\left.66 \mathrm{~kg} \mathrm{ha}^{-1} \mathrm{KCl}\right)$. The second factor was cow manure application at the rate of $2,6,8$, $10 \mathrm{Mg} \mathrm{ha}^{-1}$, respectively. Each treatment was prepared with three replications. Thus the total number of treatments was 24 experiment pots.
The soil samples were taken from tidal swampland located in Mulia Sari Village, Tanjung Lago District, Banyuasin, South Sumatra. Composite soil samples were collected from an arable layer at a $0-20 \mathrm{~cm}$ depth and taken at a predetermined location on the coordinates S $02^{\circ} 41^{\prime} 24^{\prime \prime}$ dan E $104^{\circ} 45^{\prime} 25^{\prime \prime}$. The soil analysis variables were $\mathrm{pH}$, total N, P, K, Na, Ca, Mg-exchangeability), CEC, exchangeable-Al, exchangeable- $\mathrm{H}$, and soil texture. The total-N, Bray-P, and exchangeable- $\mathrm{K}$ values obtained were used as references to calculate the location-specific fertilizer requirements for rice plants or NPK in situ. The soil from the field was then air drained for several days. Next, Air-dried soil was mashed with a soil grinder and separated from the remains of plant roots. Finally, $10 \mathrm{~kg}$ of absolute dry soil was put into the plastic pot as a planting medium. Plant variables observed were the vegetative component and the grain.

\section{Fertilization Application}

Cow manure was applied and mixed thoroughly with the soils two weeks before planting. After that, the NPK fertilizer was applied, especially Urea which was broadcasted three times, namely at the beginning of rice planting, at 14 and 28 days after planting. Meanwhile, $\mathrm{K}$ and $\mathrm{P}$ fertilizers were applied once at the beginning of planting. After that, N, P, K specific fertilizer was given based on fertilizer requirements. The treatment soil was maintained in flooding condition at $5 \mathrm{~cm}$ flooding, and each pot remained one crop. The rice seed used in the experiment was INPARA 8 variety.

\section{Data Analysis}

Data were analyzed by a two-way factorial analysis of variance (ANOVA)-procedure and and for those that have a significant effect, continue with Least Significance Different (LSD) test. For statistical analysis Excel software was used.

\section{RESULTS AND DISCUSSION}

\section{Tidal Soil Characteristics}

The soil used for this greenhouse experiment came from tidal swampland with A typology (inundated during high and low tides), and this soil was collected from Mulya Sari transmigration area, Banyuasin, South Sumatra. As shown in Table 1, the soil was classified into acid sulfate soil with low pH amounting to 4.49 (Prasetyo et al. 2001). Aksani et al. (2018) found that similar tidal soil had a $\mathrm{pH}$ of 4.57. Moreover, Fahmi et al. (2018) reported that 
Table 1. Initial Soil properties of tidal swampland Mulya Sari, Banyuasin

\begin{tabular}{lcrl}
\hline \multicolumn{1}{c}{ Variable } & Unit & Value & Note* \\
\hline $\mathrm{pH} \mathrm{H} \mathrm{H}_{2} \mathrm{O}(1: 1)$ & & 4.49 & Acid \\
C-Organic & $\mathrm{g} \mathrm{kg}^{-1}$ & 4.75 & High \\
N-total & $\mathrm{g} \mathrm{kg}^{-1}$ & 0.28 & Medium \\
Available-P (Bray I) & $\mathrm{mg} \mathrm{kg}^{-1}$ & 28.00 & High \\
K-exchangeability & $\mathrm{cmol}(+) \mathrm{kg}^{-1}$ & 0.76 & High \\
Na-exchangeability & $\mathrm{cmol}(+) \mathrm{kg}^{-1}$ & 0.44 & Medium \\
Ca-exchangeability & $\mathrm{cmol}(+) \mathrm{kg}^{-1}$ & 0.91 & Very Low \\
Mg-exchangeability & $\mathrm{cmol}(+) \mathrm{kg}^{-1}$ & 0.13 & Very Low \\
$\mathrm{CEC}$ & $\mathrm{cmol}(+) \mathrm{kg}^{-1}$ & 15.95 & Low \\
Al-exchangeability & $\mathrm{cmol}(+) \mathrm{kg}^{-1}$ & 3.09 & \\
H-exchangeability & $\mathrm{cmol}(+) \mathrm{kg}^{-1}$ & 0.84 & \\
Texture: & & & Sandy Loam \\
Sand & $\%$ & 53.54 & \\
Silt & $\%$ & 31.52 & \\
Loam & $\%$ & 14.93 & \\
\hline
\end{tabular}

*) Based on the criteria of soil characteristics proposed by the Soil Research Institute (1983)

soil inundation increases the $\mathrm{pH}$ of tidal soil due to the reduction process. Low $\mathrm{pH}$ in combination with $\mathrm{Al}^{3+}$ and $\mathrm{H}^{+}$exchangeability was obtained in this tidal soil with the value of 3.09 and $0.84 \mathrm{cmol}(+)$ $\mathrm{kg}^{-1}$, respectively (Table 1). Budianta et al. (2017) found comparable results of this tidal soil, and the low $\mathrm{pH}$ in this soil has corresponded to low extractable-Ca and $\mathrm{Mg}$ with the value of 0.91 and $0.13 \mathrm{cmol}(+) \mathrm{kg}^{-1}$, respectively. An almost similar result of initial characteristics of this soil was found by Aksani et al. (2018).

A high content of $\mathrm{K}$ exchangeability with a value of $0.74 \mathrm{cmol}(+) \mathrm{kg}^{-1}$ and Bray-P $28 \mathrm{mg} \mathrm{kg}^{-1}$ were found in this acidic soil. The high potassium and phosphorus in soil were possibly due to applied NPK fertilizer in long-term fertilization, which was more than 30 years old (Budianta et al. 2017). The soil texture is sandy loam with particle distribution consisting of $53.54 \%$ sand, $31.52 \%$ silt, and $14.93 \%$ loam. Lyu et al. (2015) also reported that the soil texture of tidal soil from the Yellow River Delta varied from silt loam to sandy loam. Budianta et al. (2019) reported that the soil texture of tidal soil of D typology in the same district was classified in clay loam texture.

Moreover, the other soil chemistry characteristics of this tidal soil used for this experiment, as presented in Table 1, were organic$\mathrm{C} 4.75 \mathrm{~g} \mathrm{~kg}^{-1}$ or organic matter content amounting to $8.189 \%$, total-N $0.28 \mathrm{~g} \mathrm{~kg}^{-1}$, exchangeable $\mathrm{Na}$ $0.44 \mathrm{cmol}(+) \mathrm{kg}^{-1}$, Cation Exchange Capacity 15.95 cmol $(+) \mathrm{kg}^{-1}$, exchangeable-Al $3.09 \mathrm{cmol}(+) \mathrm{kg}^{-1}$, and exchangeable- $\mathrm{H} 0.84 \mathrm{cmol}(+) \mathrm{kg}^{-1}$. According to Toha (2005), if the soil having $\mathrm{N}$ content is less than $0.25 \%$, the rice plant will experience starvation (deficiency), resulting in the growth stage will be disrupted. In addition, $\mathrm{N}$ deficiency in plants will reduce yield and decrease the quality of rice. Imanudin and Armanto (2012) reported that the dynamics of soil nutrients status in tidal soil are frequently affected by soil water status at the crop's root zone. For example, organic-C values varied from low to high status, total- $\mathrm{N}$ values were in the range of low to medium, whereas phosphorus values were in the range of medium to high and potassium values were also low so that the soil fertility general is relatively low. Based on N-total, P-available, $\mathrm{K}$ exchangeability, and soil pH obtained (Table 1), this tidal soil is included in the land suitability class category S2 (quite suitable) for rice plants tidal soil was included low fertility. Therefore, it is necessary to evaluate the specific location fertilizer based on in situ N, P, K, and cow manure to increase tidal swamp for rice production.

\section{Characteristics of Cow Manure}

Cow manure is one kind of bio-organic material produced from cow feces combined with urine. The cow manure used for this experiment was taken from a local farm. Gupta et al. (2016) stated that cow dung (manure) was defined as the undigested residue of consumed food material being excreted by herbivorous bovine animal species (a mixture of feces and urine in the ratio 1:3), and cow manure is not only an agricultural waste but also an organic fertilizer resource (Zhang et al. 2020). Feedlot cattle 
Table 2. Characteristics of cow manure from the local farm.

\begin{tabular}{lccc}
\hline \multicolumn{1}{c}{ Parameter } & Unit & Value* & SNI** \\
\hline $\mathrm{pH} \mathrm{H}_{2} \mathrm{O}(1: 2,5)$ & & 8.43 & $4-8$ \\
Total N & $\%$ & 1.037 & - \\
P- extractable & $\%$ & 0.855 & $<5$ \\
K-extractable & $\%$ & 0.750 & $<5$ \\
\hline
\end{tabular}

*) Based on the analysis results of the Laboratory of Chemistry and Soil Fertility, Department of Soil, Faculty of Agriculture, Sriwijaya University.

**) Compost quality standards (2009)

can generate manure for about $5-6 \%$ of their body weight each day (Font-Palma (2019). Raj et al. (2014), cow manure or cow dung can be used as a source of bio-fertilizer with low price and easy to find out.

The application of composted cow manure can increase essential nutrients such as $\mathrm{N}, \mathrm{P}$, and $\mathrm{K}$, and soil pH (Das et al. 2017), and cow manure can also improve soil health (Raj et al. 2014). Data of cow manure properties used in this experiment presented in Table 2. Cow manure has high $\mathrm{pH}$ with a value of 8.43 , which means that cow manure is alkalis condition, and it contained total $\mathrm{N} 1.037 \%$, extractable-P, and K respectively to 0.855 and $0.75 \%$ (Table 2). Cow manure contained 24 different element minerals included macro and microelements (Gupta et al. 2016). It indicated that this cow manure is fertile and can be used as an organic fertilizer. Unfortunately, tomatoes with poultry manure gave a higher yield with a value of $28 \mathrm{Mg}$ ha $^{-1}$ than cow dung's application only with a $3.5 \mathrm{Mg}$ ha $^{-1}$ (Usman 2015).

Irshad et al. (2013) reported that cow manure has a pH of 8.5 in fresh form and $\mathrm{pH} 7.4$ in compost; moreover, in a compost of $\mathrm{pH} 7.86$ (Huang et al. 2017) and $\mathrm{pH} 7.75$ (Novia et al. 2019).
Furthermore, Huang et al. (2017) analyzed that cattle manure contained $\mathrm{N}-\mathrm{NH}_{4}^{+}$and $\mathrm{N}-\mathrm{NO}_{3}{ }^{-}$with the value of 0.02 and $0.7 \mathrm{~g} \cdot \mathrm{kg}^{-1}$. From this point of view, cow manure can be used as a nutrient source for plant growth. However, cow manure or cow dung's quality depends on the fed (Kiyasudeen et al. 2015). Soil with cow manure had a high $\mathrm{pH}$ in summer, but the $\mathrm{pH}$ decreased under tea plantations (Zhang et al. 2020).

\section{Rice Growth and Yield}

The cow manure treatment had a significant effect on plant height, number of maximum tillers, number of productive tillers, and grain yields per ha, but had a non-significance effect on the weight of 1000 grains and grain weight per clump. In contrast, the NPK recommendation and specific location fertilization had no significant effect on all observed component growth and rice yield. The combination of the two factors also showed an insignificant effect on all observed variables (Table 3 ).

Only cow manure treatment significantly affected N, P, K uptake of rice crops at the primordial stage. Meanwhile, the NPK treatment and interaction of both gave non-significant NPK uptake of the crop (Table 3). It means that cow manure

Table 3. Statistical analysis (F-test ANOVA results) of the inorganic NPK fertilizers and cow manure treatments on the observed variables.

\begin{tabular}{lccc}
\hline \multirow{2}{*}{ Variable } & \multicolumn{3}{c}{ F- test } \\
\cline { 2 - 4 } & NPK treatment & Cow manure & Interaction \\
\hline Plant Height & $0.01^{\mathrm{ns}}$ & $11.14^{*}$ & $0.51^{\mathrm{ns}}$ \\
Maximum Tillers & $0.04^{\mathrm{ns}}$ & $12.89^{*}$ & $1.82^{\mathrm{ns}}$ \\
Productive Tillers & $0.37^{\mathrm{ns}}$ & $10.74^{*}$ & $0.45^{\mathrm{ns}}$ \\
1000-grain weight & $0.05^{\mathrm{ns}}$ & $0.57^{\mathrm{ns}}$ & $0.10^{\mathrm{ns}}$ \\
Grain Weight per Clump & $0.04^{\mathrm{ns}}$ & $3.32^{\mathrm{ns}}$ & $0.36^{\mathrm{ns}}$ \\
Grain Production per Ha & $0.23^{\mathrm{nn}}$ & $4.02^{*}$ & $0.24^{\mathrm{ns}}$ \\
N uptake & $0.07^{\mathrm{ns}}$ & $17.50^{*}$ & $0.90^{\mathrm{ns}}$ \\
P uptake & $0.20^{\mathrm{ns}}$ & $4.64^{*}$ & $1.04^{\mathrm{ns}}$ \\
K uptake & $0.97 \mathrm{~ns}$ & $14.85^{*}$ & $1.35 \mathrm{~ns}$ \\
\hline
\end{tabular}

ns $=$ non significance different 
can supply NPK for rice growth on tidal soil because many scientists reported that it could be used as a bio-organic fertilizer which cheap and easy to collect, and it can support agriculture sustainability (Raj et al. 2014). Cow manure is very safe to be used as an organic fertilizer because it contained low heavy metals (such as $\mathrm{Pb}, \mathrm{Cd}, \mathrm{Cu}$ ) compared to pig manure (Zhang et al. 2012). Cow manure also contained more $\mathrm{C}, \mathrm{N}, \mathrm{P}, \mathrm{K}, \mathrm{Ca}$, and $\mathrm{Mg}$ than sheep manure, corn biomass, and rice husk ash with the value of $28.42,1.06,0.74,1.25,1.44$, and $0.44 \%$, respectively (Sudarsono et al. 2014). It means that cow manure was highly fertile for nutrient source for plant growth.

\section{Plant height}

Plant height is an essential trait for plants because it is related to plant lodging (Fageria et al. 2013). Only cow manure application has affected the plant height, and the others did not have any significant effect on the plant height of rice grown in tidal soil. The INPARA 8 rice variety (Indonesian Center for Rice Research 2016) showed that generally, the rice plant of INPARA 8 is around 107 $\mathrm{cm}$. Based on the Standard Evaluation System for Rice (IRRI 1996), the height of rice plants is generally classified into three (3) groups, namely low (less than $100 \mathrm{~cm})$, medium $(101-130 \mathrm{~cm})$, and high (more than $130 \mathrm{~cm}$ ). INPARA 8 rice variety is included in the medium group, which is $107 \mathrm{~cm}$ plant height. The difference in plant height is influenced by plant varieties or the plant's genetic factors (De Datta 1981). The data shown in Table 4 shows that the plant height of the pot experiment obtained was below $107 \mathrm{~cm}$. It meant that organic fertilizer and cow manure in tidal soil did not increase the plant height above $107 \mathrm{~cm}$ (Which ranged from $69.77 \mathrm{~cm}$ to $94.03 \mathrm{~cm}$ ). The highest plant height was found on the application of cow dung at $10 \mathrm{Mg} \mathrm{ha}^{-1}$ combined with NPK specific location fertilizer, but it was not significant compared to NPK recommendation (Table 4). Aksani et al. (2018) obtained that the maximum rice height of INPARA 4 planted in tidal soil of A typology is around $89.50 \mathrm{~cm}$.

The data presented in Table 4 showed that the height of the rice plant did not reach the description of the INPARA 8 variety. Plant height was influenced by internal and external factors such as genetic factors, temperature, water, humidity, soil, essential nutrient content, light intensity, and nitrogen content in the soil. Nitrogen is the essential nutrient for vegetative growth. The need for $\mathrm{N}$ is higher than other nutrients (Duan et al. 2007).

Iron is one of the essential nutrients for rice. As an essential element needed by plants, Iron has many vital roles in plant metabolic processes such as photosynthesis, respiration, and the main constituent of cell protein (Connolly and Guerinot 2002). In plants, Fe functions as a constituent of chlorophyll, a cofactor enzyme, and plays a role in developing chloroplasts. Iron also plays a role in electron transfer in respiration (Suhartini 2004). Iron deficiency causes inhibition of chlorophyll formation, and the function of some enzymes is imperfect. However, Iron is toxic when it is accumulated in large amounts in plant tissue. Iron toxicity only occurs in soils that have been inundated for an extended period by reducing the redox potential of the soil, causing $\mathrm{Fe}^{3+}$ in soil minerals to be reduced to $\mathrm{Fe}^{2+}$, which is more water-soluble, thus triggering iron overload and even the concentration reaches $1000 \mathrm{mg} \mathrm{L}^{-1}$ (Kirk 2004). Iron concentration in plant tissue is expected in the range of 100-200 ppm, and if the $\mathrm{Fe}$ content in the soil is at a concentration of more than $300 \mathrm{ppm}$, it can cause poisoning in rice plants (Tanaka 1972). However, Fe content in tidal soil is higher in dry conditions than wet conditions (Imanudin and Armanto 2012).

\section{Maximum Tillers}

A tiller is a stem produced by a rice crop and refers to all shoots that grow after the initial parent shoot grows from a seed, and maximum tillers are

Table 4. Effect of inorganic fertilizer and cow manure on plant height $(\mathrm{cm})$.

\begin{tabular}{|c|c|c|c|c|}
\hline \multirow{2}{*}{ Treatment } & \multicolumn{4}{|c|}{ Cow manure } \\
\hline & $2 \mathrm{Mg} \mathrm{ha}^{-1}$ & $6 \mathrm{Mg} \mathrm{ha}^{-1}$ & $8 \mathrm{Mg} \mathrm{ha}^{-1}$ & $10 \mathrm{Mg} \mathrm{ha}^{-1}$ \\
\hline & \multicolumn{4}{|c|}{---- Plant height $(\mathrm{cm})$---- } \\
\hline NPK Recommended & $71.30^{\mathrm{a}}$ & $85.433^{\mathrm{b}}$ & $92.97^{\mathrm{b}}$ & $89.63^{b}$ \\
\hline NPK specific location & $69.77^{\mathrm{a}}$ & $87.033^{\mathrm{b}}$ & $87.67^{b}$ & $94.03^{b}$ \\
\hline $\operatorname{LSD} \alpha=0.05$ & \multicolumn{4}{|c|}{12.39} \\
\hline
\end{tabular}


Table 5. Effect of inorganic fertilizers and cow manure on maximum tillers.

\begin{tabular}{lcccc}
\hline \multirow{2}{*}{ Treatment } & \multicolumn{3}{c}{ Cow manure } \\
\cline { 2 - 4 } & $2 \mathrm{Mg} \mathrm{ha}^{-1}$ & $6 \mathrm{Mg} \mathrm{ha}^{-1}$ & $8 \mathrm{Mg} \mathrm{ha}^{-1}$ & $10 \mathrm{Mg} \mathrm{ha}^{-1}$ \\
\hline NPK Recommended & $8.33^{\mathrm{abc}}$ & $8.00^{\mathrm{ab}}$ & $11.67^{\mathrm{cd}}$ & $16.00^{\mathrm{e}}$ \\
NPK specific location & $7.33^{\mathrm{a}}$ & $11.33^{\mathrm{bcd}}$ & $12.00^{\mathrm{d}}$ & $14.00^{\mathrm{de}}$ \\
\hline LSD $\alpha=0.05$ & & 3.64 & \\
\hline Note: The numbers followed by the same letter in the same row are not significantly different at the 5\% LSD test level
\end{tabular}

the total of tillers grown during rice growth. Optimum tillering is very important to develop primary and secondary tillers, all bearing healthy panicles. This concept is recent, displacing wide tillering rice varieties (Pawar et al. 2016). The statistical analysis results showed that only cow manure had the significant effect on maximum tillers, and inorganic NPK fertilizer and interaction of both did not significantly differ. On the contrary, (Aksani et al. 2018) found that NPK fertilizer significantly affected the maximum tiller of INPARA4. As shown in Table 5 , the maximum tillers were found in the treatment of NPK recommendation combined with cow manure at $10 \mathrm{Mg} \mathrm{ha}^{-1}$ with 16 stems, but not significantly different from NPK specific location fertilizer with a value of 14 stem. It indicated that cow manure could supply nutrients used for rice growth. It is estimated, cow manure can supply $\mathrm{N}$, $\mathrm{P}$, and $\mathrm{K}$, amounting to about $103.7,85.5$, and $75 \mathrm{~kg}$ $\mathrm{ha}^{-1}$, respectively, based on the calculation nutrients of cow manure as shown in Table 2. These three essential elements are beneficial for plant growth. Nitrogen and $\mathrm{P}$ are nutrients that plants need in large quantities. Nitrogen is an essential element in the formation of chlorophyll. Lack of $\mathrm{N}$ and $\mathrm{P}$ can inhibit the formation of rice tillers (Gani and Sembiring 2007). The more $\mathrm{N}$ and $\mathrm{P}$ nutrients are given, the more tillers that are formed can occur. Nitrogen elements are an essential nutrient for plants, and the response of rice plants to $\mathrm{N}$ is usually higher than $\mathrm{P}$ and $\mathrm{K}$ nutrients. Based on the study results, the maximum number of tillers with higher doses of cow manure showed a positive response. Rice treated with high fertilizer doses of cow manure showed a higher maximum number of tillers. Aksani et al. (2018) reported that with higher doses of $\mathrm{N}$, $\mathrm{P}, \mathrm{K}$ fertilizers combined with straw compost of 10 $\mathrm{Mg} \mathrm{ha}{ }^{-1}$, the number of tillers produced would increase.

According to Abdullah (2016), the maximum number of tillers was reached at the age of 50-70 days after planting, then the chicks that were formed after reaching the maximum limit would decrease and even stop due to weakened growth. Rice plants are in the flowering period, and panicles appear at the age above 70 days after planting.

\section{Productive Tillers}

A productive tiller is a stem produced by a rice crop beside the main stem yielding grain. The number of productive tillers is determined by the number of tillers that grow before the primordial stage. These tillers can potentially form panicles or not form panicles (Soemartono et al. 1984). This panicle formation is influenced by the spacing, according to Masdar et al. (2001), the farther the spacing, the more productive tillers per clump. In addition to the spacing, the $\mathrm{N}$ nutrient is also a factor in panicle formation, and nitrogen is a very influential

Table 6. Effect of inorganic fertilizers and cow manure on productive tillers.

\begin{tabular}{lcccc}
\hline \multirow{2}{*}{ Treatment } & \multicolumn{3}{c}{ Cow manure } \\
\cline { 2 - 4 } & $2 \mathrm{Mg} \mathrm{ha}^{-1}$ & $6 \mathrm{Mg} \mathrm{ha}^{-1}$ & $8 \mathrm{Mg} \mathrm{ha}^{-1}$ & $10 \mathrm{Mg} \mathrm{ha}^{-1}$ \\
\hline NPK Recommended & $6.67^{\mathrm{a}}$ & $7.00^{\mathrm{a}}$ & $9.67^{\mathrm{ab}}$ & $13.33^{\mathrm{c}}$ \\
NPK specific location & $7.00^{\mathrm{a}}$ & $9.00^{\mathrm{a}}$ & $10.00^{\mathrm{abc}}$ & $12.67^{\mathrm{bc}}$ \\
\hline LSD $\alpha=0.05$ & & \multicolumn{3}{c}{} \\
\hline
\end{tabular}

Note: The numbers followed by the same letter in the same row are not significantly different at the $5 \%$ LSD test level 
element in plants. This element plays a significant role in stimulating plant vegetative growth, where the $\mathrm{N}$ nutrient is a building block of amino and nucleate, which is used to form rice plant tillers and produce panicles (Triadiati et al. 2012).

According to Winarso (2005), in addition to playing a role in plant vegetative growth, $\mathrm{N}$ also plays a role in forming the number of productive tillers. The higher the $\mathrm{N}$ content and $\mathrm{N}$ uptake, the number of productive tillers would also increase. The addition of organic matter derived from animal manure and adding soil organic matter also contributes to N, P, and K nutrients. Rusdiansyah and Saleh (2017) reported that a different effect of $\mathrm{N}$ fertilizer was observed on the number of tillers per hill, percentage of filled grain per panicle, and weight of 1000 grains. The highest productive tillers for this experiment were found when the rice was fertilized by NPK recommendation combined with 10 $\mathrm{Mg} \mathrm{ha}^{-1}$ cow manure with a value of 13.33 steams but not significantly different compared to specific fertilizer combined with the exact dosage of cow manure.

Moreover, the lowest productive tillers were found at the lowest cow manure dose (Table 6). The low number of productive tillers is thought to be due to the influence of $\mathrm{Al}$ and $\mathrm{Fe}$, which can bind the elements $\mathrm{N}$ and $\mathrm{P}$, which then creates a deficiency in nutrients which then causes disrupted growth. In addition, at the lowest dose, cow manure will also supply the lowest $\mathrm{N}, \mathrm{P}$, and $\mathrm{K}$ nutrients. For example, Aksani et al. (2018) reported that the highest productive tiller with a value of 40 stems was found when rice of INPARA 4 was fertilized NPK at the rate of $315 \mathrm{~kg}^{-1} \mathrm{urea}^{-1}+135 \mathrm{~kg} \mathrm{SP}-36$ $\mathrm{ha}^{-1}+90 \mathrm{~kg} \mathrm{KCl} \mathrm{ha}{ }^{-1}$ combined with $10 \mathrm{Mg} \mathrm{ha}^{-1}$ of rice straw compost.

\section{0-Grain Weight}

Thousand-grain weight obtained varied from 17.12 to $19.90 \mathrm{~g}$, and the highest 1000 -grain weight (19.9 g) was obtained at NPK recommendation combined with at $10 \mathrm{Mg} \mathrm{ha}^{-1}$ cow manure, but it is not different with NPK specific location fertilization at the same rate of cow manure (Table 7). Kumar et al. (2013) obtained $27.7 \mathrm{~g}$ of 1000-grain weight planted in the lowland. The lowest 1000-grainweight of this experiment was obtained at the application of NPK recommendation combined with $8 \mathrm{Mg} \mathrm{ha}^{-1} \mathrm{cow}$ manure with a value of $15.55 \mathrm{~g}$. This 1000 -grain weight obtained from this experiment is still below compared to the description of INPARA 8 variety which is $27.2 \mathrm{~g}$; this is probably due to the infertile tidal soil resulting in low tiller. According to Fageria et al. (2013), the 1000-grain weight had a linear correlation with grain yield. Abbasi and Sepaskhah (2011) reported that the 1000-grain weight of rice could control the yield, and the number of grains per panicle $>$ number of panicles per unit area $>$ unfilled grain percentages can also control the yield of rice.

Grain weight is also influenced by $\mathrm{N}$ and $\mathrm{P}$ nutrients, affecting the size of lemma and palea. The weight of more than 1000 grains is determined by the shape of the grain (Matshusima and Muratha

Table 7. Effect of inorganic fertilizers and cow manure on the weight of 1000 grain $(\mathrm{g})$.

\begin{tabular}{lcccc}
\hline \multirow{2}{*}{ Treatment } & \multicolumn{4}{c}{ Cow manure } \\
\cline { 2 - 5 } & $2 \mathrm{Mg} \mathrm{ha}^{-1}$ & $6 \mathrm{Mg} \mathrm{ha}^{-1}$ & $8 \mathrm{Mg} \mathrm{ha}^{-1}$ & $10 \mathrm{Mg} \mathrm{ha}^{-1}$ \\
\hline NPK Recommended & $17.12^{\mathrm{a}}$ & $16.40^{\mathrm{a}}$ & $15.55^{\mathrm{a}}$ & $19.90^{\mathrm{a}}$ \\
NPK specific location & $17.27^{\mathrm{a}}$ & $16.49^{\mathrm{a}}$ & $15.77^{\mathrm{a}}$ & $17.76^{\mathrm{a}}$ \\
\hline LSD $\alpha=0.05$ & \multicolumn{4}{c}{2.88} \\
\hline
\end{tabular}

Note: The numbers followed by the same letter in different columns are not significantly different at the $5 \%$ LSD test level.

Table 8. Effect of inorganic fertilizers and cow manure on grain weight $(\mathrm{g})$.

\begin{tabular}{lcccc}
\hline \multirow{2}{*}{ Treatment } & \multicolumn{4}{c}{ Cow manure } \\
\cline { 2 - 5 } & $2 \mathrm{Mg} \mathrm{ha}^{-1}$ & $6 \mathrm{Mg} \mathrm{ha}^{-1}$ & $8 \mathrm{Mg} \mathrm{ha}^{-1}$ & $10 \mathrm{Mg} \mathrm{ha}^{-1}$ \\
\hline NPK Recommended & $9.43^{\mathrm{a}}$ & $---3^{\mathrm{a}}$ & $12.17^{\mathrm{ab}}$ & $15.97^{\mathrm{b}}$ \\
NPK specific location & $10.10^{\mathrm{a}}$ & $10.80^{\mathrm{ab}}$ & $11.53^{\mathrm{ab}}$ & $13.73^{\mathrm{ab}}$ \\
\hline LSD $\alpha=0.05$ & \multicolumn{4}{c}{5.36} \\
\hline
\end{tabular}

Note: The numbers followed by the same letter in the same row are not significantly different at the 5\% LSD test level 
1980). Grains that are oval and large will have a more significant weight than grain that is round form. The 1000 grains weight is also influenced by the condition after flowering, for example, the availability of nutrients, good weather, and the number of leaves.

\section{Grain Weight per Clump}

Grain weight per clump varied from 9.43 to $15.97 \mathrm{~g}$. The highest grain weight per clump was obtained, around $15.97 \mathrm{~g}$, which was found at NPK recommendation combined with $10 \mathrm{Mg} \mathrm{ha}^{-1}$ cow manure. However, it was not significant compared to location-specific fertilization combined with the highest rate of cow manure. On the other hand, inorganic fertilizer combined with the lowest cow fertilizer was found the lowest grain weight per clump with a value of $9.43 \mathrm{~g}$ (Table 8). The $62 \%$ of grain yield is influenced by genotypes (Fageria et al. 2013). Furthermore, the rice grain yield was controlled mainly by 1000 -grain weight, number of grains per panicle, number of panicles per unit area, and unfilled grain percentages (Abbasi and Sepaskhah 2011).

\section{Grain yield per hectare}

The rice yield per ha varied from 1.50 to 2.55 $\mathrm{Mg} \mathrm{ha}^{-1}$, and the highest yield was found at the application of NPK recommendation combined with the cow manure at dosage $10 \mathrm{Mg} \mathrm{ha}^{-1}$ with a value of $2.553 \mathrm{Mg} \mathrm{ha}^{-1}$. This study showed that some of each treatment did not achieve potential yield production with a value of $6 \mathrm{Mg} \mathrm{ha}^{-1}$; it is due to the low fertility of the tidal soil. It is also assumed that the non-fulfillment of the number of nutrients $\mathrm{N}, \mathrm{P}$, $\mathrm{K}$ needed by plants is a factor in not reaching the potential yields in the INPARA 8 rice plant as described, and plant productivity will be hampered and conversely, with sufficient plant nutrient needs, plant growth and productivity will be better. Mawardi et al. (2020) already reported that the productivity of rice planted in tidal soil is low, which was less than $2.5 \mathrm{Mg} \mathrm{ha}^{-1}$.

The low nutrients availability in this study is might be due to high levels of $\mathrm{Fe}$ and $\mathrm{Al}$ in the soil, which interfere with the growth of rice plants. Aluminum and $\mathrm{Fe}$ elements that dissolve a lot in acid soil will easily bind $\mathrm{P}$, so the addition of $\mathrm{P}$ fertilizer is less beneficial for plants, and the efficiency of $P$ fertilization is low. Based on Audebert and Sahrawat's (2000) results, Fe poisoning in severely affected rice plants results in poor growth, and the tillers do not grow so that the yields were meager and can even result in crop failure. Iron poisoning in lowland rice can reduce yields by 12 100\% (Noor 2012).

\section{Nutrient Uptake at the primordial stage Nitrogen Uptake}

Nitrogen uptake of vegetative growth at the primordial stage varied from 0.0379 to $0.3035 \mathrm{~g}$ plant $^{-1}$. The highest $\mathrm{N}$ uptake was obtained when NPK fertilized rice in situ treatment combined with the highest rate of cow manure with an $\mathrm{N}$ uptake value of $0.3310 \mathrm{~g} \mathrm{plant}^{-1}$, but this $\mathrm{N}$ uptake was not significant compared to NPK recommendation.

Table 9. Effect of inorganic fertilizers and cow manure on grain production per hectare (Mg).

\begin{tabular}{lcccc}
\hline \multirow{2}{*}{ Treatment } & \multicolumn{4}{c}{ Cow manure } \\
\cline { 2 - 5 } & $2 \mathrm{Mg} \mathrm{ha}^{-1}$ & $6 \mathrm{Mg} \mathrm{ha}^{-1}$ & $8 \mathrm{Mg} \mathrm{ha}^{-1}$ & $10 \mathrm{Mg} \mathrm{ha}^{-1}$ \\
\hline NPK Recommended & \multicolumn{5}{c}{--- grain production per hectare (ton) ---- } \\
NPK specific location & $1.510^{\mathrm{a}}$ & $1.540^{\mathrm{a}}$ & $1.946^{\mathrm{a}}$ & $2.553^{\mathrm{ab}}$ \\
\hline LSD $\alpha=0.05$ & $1.620^{\mathrm{ab}}$ & $1.503^{\mathrm{ab}}$ & $1.846^{\mathrm{ab}}$ & $2.200^{\mathrm{b}}$ \\
\hline
\end{tabular}

Note: The numbers followed by the same letter in the same row are not significantly different at the $5 \%$ LSD test level

Table 10. Effect of inorganic fertilizers and cow manure on nitrogen uptake (g plant $\left.{ }^{-1}\right)$.

\begin{tabular}{lcccc}
\hline Treatment & \multicolumn{3}{c}{ Cow manure } \\
\cline { 2 - 5 } & $2 \mathrm{Mg} \mathrm{ha}^{-1}$ & $6 \mathrm{Mg} \mathrm{ha}^{-1}$ & $8 \mathrm{Mg} \mathrm{ha}^{-1}$ & $10 \mathrm{Mg} \mathrm{ha}^{-1}$ \\
\hline NPK Recommended & $0.0379^{\mathrm{a}}$ & $0.1010^{\mathrm{ab}}$ & $0.2336^{\mathrm{cd}}$ & $0.3025^{\mathrm{d}}$ \\
NPK specific location & $0.0514^{\mathrm{ab}}$ & $0.1551^{\mathrm{bc}}$ & $0.1667^{\mathrm{bc}}$ & $0.3310^{\mathrm{d}}$ \\
\hline LSD $\alpha=0.05$ & \multicolumn{4}{c}{0.117} \\
\hline
\end{tabular}

Note: The numbers followed by the same letter in the same row are not significantly different at the 5\% LSD test level 
Meanwhile, the lowest $\mathrm{N}$ uptake was obtained at the lowest rate of cow manure (Table 10). Thus, it seems that increasing the application of cow manure can increase $\mathrm{N}$ uptake both at the application of NPK recommendation or NPK specific location. The increasing $\mathrm{N}$ uptake at the highest cow manure compare to the lowest rate is $87.47 \%$ at recommendation fertilization and $84.47 \%$ at specific location fertilizer. Malav and Ramani (2016) reported that the $\mathrm{N}$ content was significantly influenced by various $\mathrm{N}$ and $\mathrm{Si}$ application levels and their interaction.

Before the experiment, the tidal soil had a total $\mathrm{N}$ of $0.28 \mathrm{~g} \mathrm{~kg}^{-1}$. After the research, the total $\mathrm{N}$ value of the soil increased in the combination of 10 $\mathrm{Mg} \mathrm{ha}^{-1}$ of cow manure treatment. The increase in total $\mathrm{N}$ is in line with the $\mathrm{N}$ uptake at the primordial stage. The addition of organic cow manure is an effort to increase the availability of $\mathrm{N}$ that the plant can absorb. According to Supriyo and Sutanto (1999), organic matter can increase the total $\mathrm{N}$ soil.

\section{Phosphorus Uptake}

Phosphorus uptake of rice at the primordial stage varied from 0.0051 to $0.0494 \mathrm{~g} \mathrm{plant}^{-1}$ (Table 11). It is shown that the uptake of $\mathrm{P}$ is lower than $\mathrm{N}$ uptake (Table 10). It indicated that nitrogen is more needed for rice growth than P. It is also seen that the increased rate of cow manure tends to increase rice production at the primordial stage.

Soil P-Bray at the beginning of the research was $28 \mathrm{mg} \mathrm{kg}^{-1}$. At a primordial stage, $\mathrm{P}$ uptake ranged from $0.0051-0.0494 \mathrm{~g} \mathrm{plant}^{-1}$ after application of NPK recommendation and in situ NPK. According to Basyuni (2009), P is usually relatively small in soil, with a level less than $\mathrm{N}$ level, because the $\mathrm{P}$ source is less than the $\mathrm{N}$ source. The low content of available-P since $P$ is quickly bonded with $\mathrm{Al}$ and $\mathrm{Fe}$ elements in acidic soils, resulting in $\mathrm{P}$ deficiency, high P fixation by $\mathrm{Al}, \mathrm{Mn}$, and Fe. In general, $\mathrm{P}$ deficiency is due to the strong bonding of these elements such as type 1: 1 clay minerals and $\mathrm{Al}$ and $\mathrm{Fe}$ oxides and the reaction between $\mathrm{P}$ and $\mathrm{Al}$, so that $\mathrm{P}$ elements are not available for plants. It has been reported that the application of organic matter, such as animal manure, can decrease $P$ sorption and increase $\mathrm{P}$ availability in highly weathered soils (Azeez and Averbeke 2011; Guppy et al. 2005)

\section{Potassium Uptake}

Potassium $(\mathrm{K})$ uptake of rice at the primordial stage varied from 0.0683 to $0.621 \mathrm{~g} \mathrm{plant}^{-1}$. The highest $\mathrm{K}$ uptake was obtained when rice was fertilized by NPK recommendation combined with the highest rate of cow manure with a value of 0.621 g plant ${ }^{-1}$, but not significant compared to a specific location (Table 12). It shows that increasing cow manure rate increased $\mathrm{K}$ uptake of rice.

According to Bhagat et al. (2019), Potassium (K) plays a vital role in improving plant health by mitigating the severity of disease, drought, and salinity stresses and improving plants' yield. Thus, $\mathrm{K}$ is needed for plant growth. A significant increase

Table 11. Effect of inorganic fertilizers and cow manure on phosphorus uptake $\left(\mathrm{g} \mathrm{plant}^{-1}\right)$.

\begin{tabular}{lcccc}
\hline \multirow{2}{*}{ Treatment } & \multicolumn{4}{c}{ Cow manure } \\
\cline { 2 - 5 } & $2 \mathrm{Mg} \mathrm{ha}^{-1}$ & $6 \mathrm{Mg} \mathrm{ha}^{-1}$ & $8 \mathrm{Mg} \mathrm{ha}^{-1}$ & $10 \mathrm{Mg} \mathrm{ha}^{-1}$ \\
\hline NPK Recommended & $0.0051^{\mathrm{a}}$ & $0.0209^{\mathrm{ab}}$ & $0.0477^{\mathrm{cd}}$ & $0.0408^{\mathrm{bcd}}$ \\
NPK specific location & $0.0065^{\mathrm{a}}$ & $0.0233^{\mathrm{abc}}$ & $0.0232^{\mathrm{abc}}$ & $0.0494^{\mathrm{d}}$ \\
\hline LSD $\alpha=0.05$ & & \multicolumn{4}{c}{2.55} & \\
\hline
\end{tabular}

Note: The numbers followed by the same letter in the same row are not significantly different at the 5\% LSD test level

Table 12. Effect of inorganic fertilizers and cow manure on potassium uptake $\left(\mathrm{g}\right.$ plant $\left.{ }^{-1}\right)$.

\begin{tabular}{|c|c|c|c|c|}
\hline \multirow{2}{*}{ Treatment } & \multicolumn{4}{|c|}{ Cow manure } \\
\hline & $2 \mathrm{Mg} \mathrm{ha}^{-1}$ & $6 \mathrm{Mg} \mathrm{ha}^{-1}$ & $8 \mathrm{Mg} \mathrm{ha}^{-1}$ & $10 \mathrm{Mg} \mathrm{ha}^{-1}$ \\
\hline & \multicolumn{4}{|c|}{---- Potassium uptake $\left(\right.$ g plant $\left.^{-1}\right)$---- } \\
\hline NPK Recommended & $0.0683^{\mathrm{a}}$ & $0.1806^{\mathrm{ab}}$ & $0.6038^{\mathrm{cd}}$ & $0.621^{\mathrm{ad}}$ \\
\hline NPK specific location & $0.0793^{\mathrm{a}}$ & $0.2470^{\mathrm{ab}}$ & $0.3436^{\mathrm{bc}}$ & $0.5630^{\mathrm{cd}}$ \\
\hline $\operatorname{LSD} \alpha=0.05$ & \multicolumn{4}{|c|}{0.26} \\
\hline
\end{tabular}

Note: The numbers followed by the same letter in the same row are not significantly different at the 5\% LSD test level 
in vegetative and yield components of rice genotypes was found at higher potassium applications (Bhagat et al. 2019).

\section{CONCLUSIONS}

Cow manure application significantly affected vegetative growth and grain production per ha, but there is a non-significance effect on 1000 grains and grain weight per clump. In contrast, the NPK recommendation and NPK in situ fertilization had no significant effect on all observed vegetative growth and rice yield. The combination of the two factors also showed an insignificant effect on plant growth and yield. The treatment provided by recommended NPK inorganic fertilizer at $200 \mathrm{~kg}$ $\mathrm{ha}^{-1}$ Urea, $100 \mathrm{~kg} \mathrm{ha}{ }^{-1}$ SP-36, $100 \mathrm{~kg} \mathrm{ha}^{-1} \mathrm{KCl}$ combined with a $10 \mathrm{Mg} \mathrm{ha}^{-1}$ of cow dung yielded $2.55 \mathrm{Mg} \mathrm{ha}^{-1}$ grain.

\section{ACKNOWLEDGMENTS}

We are very grateful to the University of Sriwijaya that provided research funding by professional competition under contract No 0144.34/ UN9/SB3.LP2M.PT/2019.

\section{REFERENCES}

Abbasi MR and AR Sepaskhah. 2011. Response of different rice cultivars (Oryza sativa L.) to watersaving irrigation in greenhouse conditions. Inter $J$ Plant Prod 5: 37-47.

Abdullah. 2016. Study to increased lowland rice production through the specific location of nutrient management (SLNM) on the low potential productivity of lowland. J Pen Pertanian Terapan 16: 30-39

Aksani D, D Budianta and AHermawan. 2018. Determination of Site-specific NPK Fertilizer Rates for Rice Grown on Tidal Lowland. J Trop Soils 23: 19-25.

Audebert A and KI Sahrawat. 2000. Mechanism for iron toxicity tolerance in lowland rice. J Plant Nutr 23: 1877-1885.

Azeez JO and WV Averbeke. 2011. Effect of manure types and period of incubation on phosphorus-sorption indices of a weathered tropical soil. Comm Soil Sci Plant Anal 42: 2200-2218.

Basyuni Z. 2009. Mineral dan batuan sumber unsur hara P dan K. Departemen Pendidikan Nasional Universitas Jendral Soedirman Fakultas Sains dan Teknik Program Studi Teknik Geologi Purbalingga. (in Indonesian).

Bhagat MA, AR Mahar, I Rajpar, GS Channa, AA Mirbahar, MA Saand, AMajid, WB Jatoi and MH Sirohi. 2019. Potassium applications on rice (Oryza sativa L.) genotypes under saline environment. Sindh Univ. Res Jour (Sci Ser) 51: 333-338.
BBPPSLP. 2016. Inovasi Teknologi Sumberdaya Lahan Untuk Pertanian Berkelanjutan. Bogor: BBPPSLP. (in Indonesian).

Budianta D, Ermatita, A Napoleon. A Hermawan and H Wijayanti. 2017. Evaluation of some soil chemical properties of tidal swampland after long-term cultivation. Int J Engg Res Sci Tech 6: 12-21.

Budianta D, A Napoleon, A Paripurna and Ermatita. 2019. Growth and production of soybean (Glycine max (L.) Merill) with different fertilizer strategies in tidal soil from South Sumatra, Indonesia. Spanish J Soil Sci 9: 54-62.

Connolly EL and ML Guerinot. 2002. Iron stress in plants. Genome Biol 3: 1021-1024.

Das S, ST Jeong, S Das, and PJ Kim. 2017. Composted cattle manure increases microbial activity and soil fertility more than composted swine manure in a submerged rice paddy. Front Microbiol 8: 1702. doi:10.3389/fmicb.2017.01702.

De Datta SK. 1981. Principle and Practices of Rice Production. John Willey and Sons, Inc: New York. 618.

Duan YH, YL Zhang, LY Ye, XR Fan, GH Xu and QR Shen. 2007. Responses of rice cultivars with different nitrogen use efficiency to partial nitrate nutrition. Ann Bot 99: 1153-1160.

Fageria NK, A Moreira, EPB Ferreira and AM Knupp. 2013. Potassium-Use Efficiency in Upland Rice Genotypes. Commun Soil Sci Plant Anal 44: 26562665.

Fahmi A, M Alwi and D Nursyamsi. 2018. The role of inundation types of tidal swampland on the chemical properties of potentially acid sulphate soils under fertilizer and lime application. J Trop Soils 23: 55-64.

Font-Palma C. 2019. Methods for the treatment of cattle manure-A Review. J Carbon Res 5: 27. doi: 10.3390/ c5020027.

Gani A and H Sembiring. 2007. Respon padi varietas Ciherang dan Mendawak terhadap N, P dan K di tanah dari desa Tanjung, Lhoknga. Communication Forum 8 Agustus 2007 di Saree-Aceh Besar, NSW DPI-ACIAR and IARD-Indonesia. (in Indonesian).

Gupta KK, KR Aneja and D Rana. 2016. Current status of cow dung as a bioresource for sustainable development. Bioresour Bioprocess 3: 1-12.

Guppy CN, NW Menzies, PW Moody and FPC Blamey. 2005 Competitive sorption reactions between phosphorus and organic matter in soil: a review. Soil Res 43: 189-202

Hairmansis A, B Kustianto, Supartopo and Suwarno. 2010. Correlation Analysis of Agronomic Characters and Grain Yield of Rice for Tidal Swamp Areas. Indones J Agr Sci 11: 11-15

Huang J, Z Yu1, H Gao, X Yan, J Chang, C Wang, J Hu and I Zhang. 2017. Chemical structures and characteristics of animal manures and composts during composting and assessment of maturity indices. PLoS One 12: 2-16.

Imanudin MI and E Armanto. 2012. Effect of Water Management Improvement on Soil Nutrient Content, Iron and Aluminum Solubility at Tidal Low Land Area. APCBEE Procedia 4: 253-258 
IRRI. 1996. Standard Evaluation System for Rice. International Rice Research Institute : Manila, the Philipines. 49.

Irshad M, AE Eneji, Z Hussain and M Ashraf. 2013. Chemical characterization of fresh and composted livestock manures. J Soil Sci Plant Nutr 13: 115121.

Indonesian Center for Rice Research. 2016. Info.litbang.pertanian.go.id. Retrieved on November 20, 2016.

Kirk G. 2004. The biogeochemistry of submerged soils. John Wiley and Sons Ltd, England.

Kiyasudeen SK and MH Ibrahim bin SA Ismail. 2015. Characterization of fresh cattle wastes using proximate, microbial, and spectroscopic principles. Am Eurasian J Agric Environ Sci 15: 1700-1709.

Kumar R, AK Pandey, AK Singh and AK Verma. 2013. Performance of rice genotypes under low land ecosystem of Jharkhand. Environ Ecol 31: 18011805

Lyu X, J Yu, M Zhou, B Ma, G Wang, C Zhan, G Han, B Guan, H Wu, Y Li and D Wang. 2015. Changes of soil particle size distribution in tidal flats in the yellow river delta. PLoS One 10: e0121368. doi: https://doi.org/10.1371/journal.pone.0121368.

Malav JK and VP Ramani. 2016. Yield and nutrient content of rice as influenced by silicon and nitrogen application. Res J Chem Environ Sci 4: 46-49.

Masdar MK, R Bujang, H Nurhajati and Helmi. 2006. Tingkat hasil dan komponen hasil Sistem Intensifikasi Padi (SRI) tanpa pupuk organik di daerah curah hujan tinggi. J Ilmu Pertanian 8: 126-131. (in Indonesian).

Matshusima and Muratha. 1980. Fisiologi dan Moroflogi Tanaman Padi (buku 1). Balitan Pangan. Bogor. (in Indonesian).

Mawardi, BH Sunarminto, BH Purwanto, P Sudira and Gunawan. 2020. The Influence of Tidal on Fe Distribution at Tidal Swamp Rice-Farming in Barito River Area, South Kalimantan, Indonesia. BIO Web of Conferences 20: 02002. doi:10.1051/ bioconf/20202002002.

Mulyani A and I Las. (2008). Potensi sumber daya lahan dan optimalisasi pengembangan komoditas penghasil bioenergi di Indonesia. J litbang pertanian 27: 31-41. (in Indonesian).

Noor A, I Lubis, M Ghulamahdi, MA Chosin, K Anwar and D Wirnas. 2012. Pengaruh konsentrasi besi dalam larutan hara terhadap gejala keracunan besi dan pertumbuhan tanaman padi. J Agronomi Indonesia 40: 91-98. (in Indonesian).

Novia D, A Rakhmadi A, F Purwati, I Juliyarsi, R Hairani and F Syalsafilah. 2019. The characteristics of organic fertilizer made of cow feces using the Indigenous Micro-Organisms (IMO) from raw manures. IOP Conf Series: Earth Environ Sci 287: 012025. doi:10.1088/1755-1315/287/1/012025
Pawar SY, VV Radhakrishnan and KV Mohanan. 2016. The importance of optimum tillering in rice-an overview. South Indian J Biol Sci 2: 125127.

Prasetyo BH, S Suping, H Subagyo, Mujiono and H Suhardjo. 2001. Characteristics of rice soils from the tidal flat areas of Musi Banyuasin, South Sumatra. Indones J Agr Sci 2: 10-26.

Raj A, MK Jhariya and P Toppo. 2014. Cow Dung for Ecofriendly and Sustainable Productive Farming. Int J Scientific Res 3: 201-202.

Rochmat HF dan Sugiyanta. 2010. Pengaruh Pupuk Organik dan Anorganik Terhadap Pertumbuhan dan Hasil Padi Sawah (Oryza sativa L.). Makalah Seminar Departemen Agronomi dan Hortikultura IPB. (in Indonesian).

Rusdiansyah and M Saleh. 2017. Response of Two Local Rice Cultivars to Different Doses of Nitrogen Fertilizer in Two Paddy Fields. AGRIVITA J Agr Sci 39: 137-144.

Saragih S. 2013. Empat Kunci Sukses Pengelolaan Lahan Rawa Pasang Surut untuk Usaha Pertanian Berkelanjutan. Admin : Yoan Destina, 16 Agustus 2013. (in Indonesian).

Senewe RE and JB Alfons. 2011. Kajian adaptasi beberapa varietas unggul baru padi sawah pada sentra produksi padi di Seram bagian Barat propinsi Maluku. J Budidaya Pertanian 7:60-64. (in Indonesian).

Soemartono, Bahrin, Hardjono dan Iskandar. 1984. Bercocok Tanam Padi. CV Yasaguna. Jakarta.

Sudarsono WA, M Melati M and SAAziz. 2014. Growth and Yield of Organic Rice with Cow Manure Application in the First Cropping Season. AGRIVITA J Agr Sci 36: 21-25.

Suhartini T. 2004. Breeding rice variety tolerant to iron toxicity. Bull Plasm Nutr 10: 1-11

Supriyo A and R Sutanto. 1999. Pengelolaan bahan organik untuk keberlanjutan hasil pola tumpang gilir jagung-kacang tanah pada tanah kering masam. Prosiding Seminar Nasional Pertanian Organik. Palembang, pp. 109-128. (in Indonesian).

Tanaka A and T Tadano. 1972. Potassium in relation to iron toxicity of the rice plant. Potash Rev 21: 112.

Toha HM, K Permadi and SJ Munarso. 2002. Pengaruh pemberian pupuk kalium dan nitrogen terhadap hasil padi dan mutu beras IR64. J Penelitian Pertanian 21: 17-25.

Triadiati, AA Pratama and S Abdurrahman. 2012. Pertumbuhan dan efisiensi penggunaan nitrogen pada padi (Oryza sativa L.) dengan pemberian pupuk urea yang berbeda. Anatomi dan Fisiologi 20: 1-14. (in Indonesian).

Usman W. 2015. Cow dung, goat, and poultry manure and their effects on the average yields and growth parameters of tomato crop. J Biol Agr Healthcare 5: 7-10. 
Winarso S. 2005. Kesuburan Tanah Dasar Kesehatan dan Kualitas Tanah. Penerbit Gava Media, Yogyakarta. (in Indonesian).

Zhang F, Y Li, M Yang and W Li. 2012. Content of Heavy Metals in Animal Feeds and Manures from nt Scales in Northeast China. Int J Environ Res Public Health 9: 2658-2668
Zhang S, L Sun, Y Wang, K Fan, Q Xu, Y Li, Q Ma, J Wang, W Ren and Z Ding. 2020. Cow manure application effectively regulates the soil bacterial community in tea plantations. BMC Microbiology 20: 190. doi: https://doi.org/10.1186/s12866-02001871-y. 